\title{
Relationship Between Family Support and Self Care Agency with the Quality of Living Type II Diabetes Patients in Prolanis Patients
}

\author{
Ferawati, Mei Fitria Kurniati \\ STIKes Insan Cendikia Husada, Bojonegoro, East Java, Indonesia \\ Corresponding author: ferasacepul@gmail.com
}

\begin{abstract}
Background: Diabetes Mellitus is a chronic disease characterized by high blood sugar level and is caused by an increase in glucose levels due to a progressive decrease in insulin secretion caused by insulin resistance. The ability of diabetic patients to do appropriate and succesful self-care habits is closely related to morbidity and mortality and significantly affect productivity and quality of life.

Purpose: This study aimed to determine the correlation between family support and self care agency with quality of life of diabetes mellitus patient type 2 .

Method: This study uses analitycal methods, namely research that explores how and why health phenomena occur with a cross-sectional approach.

Result: The results of the Spearman-Rho test that the P-value in te sig (2-tailed) column 0.123 is more than the level of significance $\alpha 0,05(0,000<0,05)$ so it can be concluded that $\mathrm{H} 0$ is accepted and $\mathrm{H} 1$ is rejected.

Conclusion: There is no relationship between self care agency and the quality of life of people with type 2 diabetes mellitus in prolanic patients.
\end{abstract}

Keywords: Diabetes mellitus, Self care, Quality of life

Received July, 28, 2019; Revised August 28, 2019; Accepted September 20, 2019

How to Cite: Ferawati., \& Kurniati, M.F. (2019). Relationship Between Family Support and Self Care Agency with the Quality of Living Type II Diabetes Patients in Prolanis Patients. Journal Of Nursing Practice, 3(1), 22-32. https://doi.org/10.30994/jnp.v3i1.62 


\section{BACKGROUND}

Diabetes mellitus (DM) is a chronic disease characterized by blood sugar levels (blood glucose) that exceeds normal values and is caused by an increase in glucose levels due to a decrease in progressive insulin secretion caused by insulin resistance. DM consists of two types, namely type $1 \mathrm{DM}$ and type $2 \mathrm{DM}$. Compared to other types of DM, the number of patients with type II DM is about $90 \%$ higher. The number of DM patients is increasing exponentially as the result of the changes in lifestyle in this era (Suyono, 2009: 3-15).

International Diabetes Federation (IDF) (2015) mentioned that there are 415 million people in the world with DM and predicted that in the next 2040 the trend will continue to increase to 642 million. DM prevalence in Indonesia is around 10 million people; which make Indonesia in $7^{\text {th }}$ place out of 10 countries with the highest DM in the world based on the survey conducted. In Indonesia, there are 17 provinces with higher DM prevalences than the national average (5.7\%). According to the data, East Java province has $1.0 \% \mathrm{DM}$ prevalence. In East Java capital city, Surabaya in 2009, there were 15,961 DM patients, and then in 2010 the number increased to 21,729 patients and to 26,613 in 2011. Whereas in Bojonegoro, based on data from the Bojonegoro Health Office, the number of DM patients in 2016 is 27,875 . Out of that number, from the results of the preliminary study, there were 35 on chronic disease management program (CDMP) DM patients in Dander Health Center.

Family is pivotal to individual growth and development; thus family becomes one of the most important aspects of nursing. Through the family nursing care approach, family nurses can modify family environment, facilitate the achievement of the family development tasks, maintain the family structure and function and help the family adapt to the stressors so they can overcome health problems independently (Friedman, 1998 in Muhtar 2016). Family support could be in the form of information, instrumental, emotional and appreciation support. Research conducted by Flynn et al., (2013) in Wachyu F.A (2016) explained that family support will help to increase knowledge about hypertension and provide motivation to achieve goals of hypertension self care.

The main aim of DM treatment is to prevent and minimize both acute and chronic complication (Ayele, K., Tesfa, B., Abebe, L., Tilahun, T., Girma, E, 2012). Complications of DM can be controlled, prevented and inhibited by controlling blood sugar levels through diabetes management activity with non-pharmacological and pharmacological approach (Waspadji, S, 2009). The goal of DM treatment will be successful if the management of diabetes is carried out based on the patient's ability to start and act independently through self-care activity (Asselstine, R.T.M, 2011 in Rantung, 2015)

The ability of DM patients to practice appropriate and successful self-care habits is closely related to morbidity and mortality and significantly affects productivity and quality of life (Ayele, et al., 2012 in Rantung, 2015). Nurses as part of health workers play an important role in changing the behavior of patients and families to establish balance and independence in self-care activities. Dorothea E. Orem (1971) in Tomey \& Alligood (2010) argued that everyone has the ability to fulfill their basic needs independently. The role of the nurse is as an agent who assists clients in returning their roles as a self-care agent. Nurses as educators and counselors provide assistance in the form of supportive-educative systems by educating the patients to be able to perform care independently and improve patient compliance in treatment (Muhtar, 2016).

DM patients need time to adapt well to lifestyle changes. Prevention and management strategy are very important in monitoring DM. Maximum monitoring and management of DM will have a positive effect on health, especially on the quality of life and 
life expectancy (Sikdar, K. C., Wang, P. P., MacDonald, D., \& Gadag, V. G, 2010). The recent finding obtained in the Rantung research (2015) was that most respondents did not carry out self-care activity optimally, since, on average, the respondents were satisfied with their quality of life. There was a relationship between self-care activity, gender and depression with the respondents quality of life. Furthermore, there was no relationship between age, education level, income, and duration of suffering from DM with the quality of life.

One of the functions of the family is as a health care function to maintain the condition of family members in order to have high productivity continously. This function becomes the primal task of the family in the health sector (Suprajitno, 2004). Families are expected to be able to meet primary health needs in order to protect and prevent diseases that families may experience. Families as a small unit consisting of several family members need help from nurses to gain information about health, especially if the family is experiencing health problems. More specifically, family support is very important thing in the elderly selfcare management. This is in line with Orem's theory which stated that family support is a basic factor that influences one's self care agency to make decision in implementing self care (Nwinee, 2011; Schnall, 2005 in F.A Wahcyu, 2016)

It is stated that family duties in the health sector included being aware of family health problems, deciding appropriate actions for families, caring for families with health problems, modifying the family environment to ensure family health and utilizing nearby health care facilities for families. For this reason, researchers are interested in raising the issue about the relationship of family support and self care agency with the quality of life of diabetes mellitus patient type 2 on CDMP in Dander Health Center.

\section{OBJECTIVE}

This study aimed to determine the correlation between family support and self care agency with the quality of life of diabetes mellitus patient type 2 on CDMP in Dander Health Center, which futher is expected to help DM patients to improve their quality of life.

\section{METHOD}

This research is a quantitative research using a correlational description research design, a research that explains whether there is a correlation between independent variables and dependent variables through testing hypotheses (Nursalam, 2016: 162). This study used analytical methods explores how and why health phenomena occur. Then analyzing the correlation dynamics between phenomena or between risk factors and effect factors was conducted (Nursalam, 2016: 163). It was continued until the conclusion was made by using a statistical test to analyze the data obtained.

The research approach used in this study is cross-sectional, a study to observe the dynamics of correlation between risk factors and effects by approaching, observing or collecting data at one particular time (point time approach). It means that each research subject is only observed once only and measurement is made based on character status or subject variables at the time of investigation (Notoadmodjo, 2012: 37). The design of this study aims to reveal the correlation between family support and self care agency with the quality of life of diabetes mellitus patient type 2 on CDMP in Dander Health Center.

The population in this study were DM patients who participated on CDMP in Dander Health Center. Meanwhile the sample in this study were DM patients who attended CDMP 


\section{Journal Of Nursing Practice}

http://thejnp.org

ISSN: 2614-3488 (print); 2614-3496 (online)

Vol.3 No.1. October 2019. Page.22-32

activities in Dander Heatlh Care using the Non-Probability Sampling sampling technique with the Accidental Sampling method. The inclusion criteria in this study were DM patients who followed CDMP in Dander, Bojonegoro Health Center and those who were willing to be respondents in the study. The location of this study is Dander Health Center. Dander Health Center is a health center located in Dander area which is located on the right side of the road addressed at Jl. Raya Dander Temayang no. 08 Kab. Bojonegoro, East Java.

The participants were assured that their engagement was voluntary, and that anonymity, privacy, and confidentiality of the data were guaranteed. Furthermore, they were informed about the purpose and the method of the study before signing a written informed consent. The questionnaires were distributed to eligible participants at the Dander Health Center, and respondents were asked to complete and return them in the same time

\section{RESULT}

Table 4.1 shows that as many as 32 respondents most of them are female, 24 respondents $(75 \%)$.

Table 4.1 Respondent Frequency Distribution Based on Gender

\begin{tabular}{cccc}
\hline No & Gender & Frequency & Percentage \% \\
\hline 1 & Male & 8 & 25 \\
\hline 2 & Female & 24 & 75 \\
\hline & Total & 32 & 100 \\
\hline
\end{tabular}

Source : January Questionnaire 2019

Table 4.2 shows that out of 32 respondents most of them worked as a housewife which is 10 respondents $(31.2 \%)$.

Table 4.2 Respondent Frequency Distribution Based on Occupation

\begin{tabular}{clcc}
\hline No & Occupation & Frequency & Percentage \% \\
\hline 1 & Housewife & 10 & 31,2 \\
\hline 2 & Merchant & 8 & 25 \\
\hline 3 & Farmer & 6 & 18,8 \\
\hline 4 & Retiree & 8 & 25 \\
\hline & Total & 32 & 100 \\
\hline
\end{tabular}

Source: January Questionnaire 2019

Table 4.3 shows that the majority of respondents had good family support which is 23 respondents ( $71.9 \%)$.

Table 4.3 Frequency Distribution Based on Family Support

\begin{tabular}{|c|c|c|c|}
\hline No & Family Support & Frequency & Percentage \% \\
\hline 1 & Good & 23 & 71,9 \\
\hline 2 & Average & 7 & 21,9 \\
\hline 3 & Poor & 2 & 6,2 \\
\hline & Total & 23 & 100 \\
\hline
\end{tabular}

Source: January Questionnaire 2019

Table 4.4 shows that the average self care agency value is 2445.69 . 
Table 4.4 Frequency Distribution Based on the Self Care Agency

\begin{tabular}{lcccc}
\hline Variable & N & Min & Max & Mean \pm SD \\
\hline Self Care Agency & 15 & 2101 & 2873 & $2445.69 \pm 188.643$
\end{tabular}

Source: January Questionnaire 2019

Table 4.5 shows that the majority (22 respondents/68.8\%) of respondents had poor quality of life which

Table 4.5 Frequency Distribution Based on Quality of Life

\begin{tabular}{|c|c|c|c|}
\hline No & Family Support & Frequency & Percentage \% \\
\hline 1 & Average & 10 & 31,2 \\
\hline 2 & Poor & 22 & 68,8 \\
\hline & Total & 32 & 100 \\
\hline
\end{tabular}

Source: January Questionnaire 2019

The results of cross tabulation in Table 4.6 found that most of the respondents who had good family support with average quality of life were 5 respondents $(21.7 \%)$ and poor quality of life were 18 respondents (78.3\%). Families that had average family support with average quality of life are 5 respondents $(71.4 \%)$ and poor quality of life are 2 respondents $(28.6 \%)$. While families that had poor family support with poor quality of life were 2 respondents $(100 \%)$.

Table 4.6 Cross Tabulation of the correlation between family support and the quality of life of diabetes mellitus patient type 2 on CDMP in Dander Health Center.

\begin{tabular}{lcccccc}
\hline \multirow{2}{*}{$\begin{array}{c}\text { Family } \\
\text { support }\end{array}$} & \multicolumn{7}{c}{ Quality of Life } \\
\cline { 2 - 7 } & \multicolumn{2}{c}{ Average } & \multicolumn{2}{c}{ Poor } & Total \\
\cline { 2 - 7 } & $\mathrm{N}$ & $\%$ & $\mathrm{~N}$ & $\%$ & $\mathrm{~N}$ & $\%$ \\
\hline Good & 5 & 21,7 & 18 & 78,3 & 30 & 100 \\
\hline Average & 5 & 71,4 & 2 & 28,6 & 7 & 100 \\
\hline Poor & 0 & 0 & 2 & 100 & 2 & 100 \\
\hline Total & 10 & 31,2 & 22 & 68,8 & 32 & 100 \\
\hline
\end{tabular}

Based on the results of Rho Speraman test, it was shown that the results of the $\mathrm{P}$-value in the sig column ( 2 tailed) obtained a value of 0.123 higher than the level of significant $\alpha 0.05(0,000<0.05)$ so that it can be concluded that $\mathrm{H} 0$ was accepted and $\mathrm{H} 1$ was rejected. This means that there is no correlation between family support and quality of life of diabetes mellitus patient type 2 on CDMP in Dander Health Center. Furthermore, the Spearman correlation value of $-0,279$ shows that the direction of the negative correlation had a very weak correlation. 
Table 4.7 The Result of the correlation between family support and quality of life of diabetes mellitus patient type 2 on CDMP in Dander Health Center.

\begin{tabular}{lllr}
\hline \multicolumn{4}{c}{ Correlations } \\
\hline
\end{tabular}

Based on the results of the Spearman Rho test, it is shown that the results of the P-value in the sig column ( 2 tailed) obtained a value of 0.751 higher than the level of significant $\alpha 0.05(0,000<0.05)$ so that it can be concluded that $\mathrm{H} 0$ was accepted and $\mathrm{H} 1$ was rejected. It means that there is no correlation between self care agency and the quality of life of diabetes mellitus patient type 2 on CDMP in Dander Health Center. The Spearman correlation value of 0.058 indicates that the direction of positive correlation had a very weak correlation.

Table 4.8 The Result of the Correlation between Self Care Agency and quality of life of diabetes mellitus patient type 2 on CDMP in Dander Health Center

\begin{tabular}{lllrr}
\hline \multicolumn{3}{c}{ Correlations } \\
\hline \multirow{2}{*}{ Spearman's rho } & \multicolumn{2}{c}{ Self Care Agency } & Kualitas Hidup \\
\cline { 3 - 5 } & Self Care Agency & Correlation Coefficient & 1.000 & .058 \\
& & Sig. (2-tailed) & .751 \\
& $\mathrm{~N}$ & 32 & 32 \\
\cline { 2 - 5 } & Quality of Life & Correlation Coefficient & .058 & 1.000 \\
& Sig. (2-tailed) & .751 & 32 \\
& $\mathrm{~N}$ & 32 &. \\
\hline
\end{tabular}

\section{DISCUSSION}

\section{The Characteristics of Respondents Who Have Diabetes Mellitus}

The factor that influences the results of this study is gender. Based on table 4.1 shows that the majority of respondents are female which are $75 \%$ or 24 respondents, whereas male respondents only $25 \%$ or 4 male respondents. According to Caplan and Sadock (2005) in Demak \& Suherman (2016), anxiety occurs more in women. Women have a high level of anxiety because of the result of excessive autonomic nerve reactions with an increase in the sympathetic system, norepineprine, as well as cotalamin release, and there is an abnormal disorder of serotonergic regulation. This shows that gender will also affect the quality of life of the elderly who have diabetes mellitus in dealing with the problem.

Based on table 4.2, it shows that from 32 respondents most of them work as housewives (10 respondents $/ 31.2 \%$ ). The other data shows that there are respondents who work as merchant and retirees as many as 8 respondents or $25 \%$, and as farmers 6 respondents or $18.8 \%$. According to the results Ansori and Martiana's research in 2017, it stated that the employment relationship is a work condition factor which is related to the occurrence of work stress. It means that the type of work done by a person also affects the 
quality of life. Meanwhile the study was conducted by Zainuddin, et al (2015) in Mirza (2017) was done to diabetes mellitus patients to see whether stress affects quality of life or not.

The research obtained significant and negative results on stress variables, the lower the stress, the higher the quality of life, on the contrary the higher the quality of life, the lower the quality of life. In this study, the majority of CDMP respondents with diabetes mellitus worked as housewives. The demand as a housewife makes someone have to work harder since they have to deal with both their husbands and children. Being a housewife is required to always be able to meet the needs of all family members, which ultimately makes the burden of housewives a little heavy.

According to Brunner and Suddarth (2013), one of the factors causing diabetes mellitus is stress. This factor will damage beta cells in the body so that it will lead to insulin insufficiency. So it is not surprising if women who work as a housewife tend to have diabetes mellitus type 2 more. Moreover, women are more susceptible to stress than men, and also the majority of respondents in this study are women with a profession as housewives.

Nursing action carried out by Dorothea Oreme was with independent nursing which means that the implementation of activity is initiated and carried out by the individual to meet the needs to maintain life, health, and well-being according to health conditions (Oren, 1980 in Maryani, 2014). That act of independence is expected to help people with diabetes mellitus to recover and be healthy. The healing process of diabetes mellitus requires patience and extra discipline because blood sugar levels can go up and down at any time if the patient does not maintain their diet properly. For this reason it is necessary to modify the environment of the nurse to the family and the patient's environment so that the patient can control the sugar content independently.

\section{Family Support toward Diabetes Mellitus Type 2 Patient.}

Meanwhile in table 4.3 the characteristics of family support show that the majority of respondents had good family support which is 23 respondents (71.9\%). Other data said that $21.9 \%$ received sufficient support and $6.2 \%$ respondents received less support. Based on these data, it can be concluded that diabetes mellitus type 2 patients had received good support from the family. In Khairani's (2014) in Kuntjoro (2002) study stated that emotional support allows someone to get emotional closeness; thus it creates a sense of security for the recipient. People who receive this kind of emotional support will feel calm, safe and comfortable which is indicated by a calm and happy attitude. This source of support is most often gained from spouses or families, close friends as well as relatives.

According to Brunner \& Suddarth (2002) in Taluta, et al (2014), diabetes mellitus will also cause some psychological impacts such as anxiety, anger, grieving, shame, guilt, hopelessness, depression, loneliness, helplessness , additionally the patients can also be passive, dependent, uncomfortable, confused and suffered. Therefore, they really need support from their closest people. The support from the closest people such as family, will build an adaptive coping mechanism so that the recovery and healing process can be controlled properly.

Family support is beneficial for a development towards a healthy personality without any disturbance (Kuntjoro, 2002 in Cahyoputro, 2008). This is in line with the views of Oreme in the independent nursing paradigm, with overall physical, mental, psychological, and social integration along with a various degrees of independent nursing ability, the level of well-being and health of individuals will increase well. 
The support from the closest family will make DM type 2 patients feel comfortable, assured to be cared for and loved so they can deal with the problems better. Family support is very important in dealing with uncontrollable circumstances. Dorothea Oreme teaches nurses to also play a role as a supporter for the patients so that the patients can continue their lives independently. Also, they can encourage the patients' family to always provide good support in order to make the patients be able to carry out their activities independently.

Furthermore, the respondents with the average quality of life are $31.2 \%$ or 10 respondents while the respondents with the poor the quality of life are 22 respondents or $68.8 \%$. One of the tasks in Oreme's self care nursing model is to modify the environment that can support health (Maryani, 2014). By making modification to the environment, the quality of family life will be better. The majority of the quality of life of the respondents in this study was poor, this is because the family had not been able to modify the environment such as utilizing health facilities around the respondent's environment.

Table 4.6 shows that from 32 respondents, who have diabetes mellitus, there are 5 respondents $(21.7 \%)$ who had good family support with average quality of life and 18 respondents $(78.3 \%)$ had poor quality of life.

One of the ways to avoid loneliness is with the support of family and people around him. The result of this study, streghtened by Hayati (2010) in Khairani (2014) research, found that family support is the most important element in solving loneliness problem. Family support is also able to provide a sense of confidence and motivation toward the patients and thus the quality of life will increase.

The Correlation between Family Support and the Quality of Life of Diabetes Mellitus Patient Type 2 on CDMP in Dander Health Center

According to the World Health Organization (WHO, 2004 in Chusmeywati, 2016), quality of life is an individual's perception of value and concept in their relationship to achieve expectations. In this study, table 4.7 shows the correlation between the relationship between the Self Care Agency and the quality of life of diabetes mellitus patient type 2 on CDMP in Dander Health Center, based on the results of the Rho series test, it is indicated that the P-value in the sig column ( 2 tailed) is 0.123 higher than the level of significant $\alpha$ $0.05(0,000<0.05)$ so that it can be concluded that $\mathrm{H} 0$ was accepted and $\mathrm{H} 1$ was rejected. This means that there is no correlation between family support and quality of life of diabetes mellitus patient type 2 on CDMP in Dander Health Center. The Spearman correlation value of $-0,279$ shows that the direction of the negative correlation had a very weak correlation.

That result contradicts the study conducted by Alvita (2016) regarding to the correlation of family support and the diabetes mellitus care of the elderly at home, the study found that there was a correlation between emotional support, award support, information, and instrumental with diabetes care in elderly with a value of $p<0.05$. In her research, Alvita (2016) stated that the support given by the family to the elderly could increase the motivation of the elderly in performing DM care so that nurses needed to increase family participation in looking after the elderly who had DM especially by providing emotional support.

In addition, Alvita's study is also in line with the results of research conducted by Yusra (2010) regarding to the relationship of family support with the quality of life of DM type 2 internal polyclinic of Fatmawati General Hospital, Jakarta, which stated that there was a correlation between family support in terms of four dimensions (emotional, appreciation, instrumental, and information) with quality of life.

According to Bomar (2004) in Yusra (2010), reward is a support or assistance from the family in the form of providing feedback and appreciation by showing a positive 
response, such as encouragement or approval of someone's ideas or feelings. Similar to this statement, in the independent Oreme nursing model there are three categories of nursing assistance given to individuals, namely wholly compensatory (full assistance), partially compensatory (partial assistance), and supportive-educative (educational support). If analyzed from the three assistances, it can be concluded that in order to achieve independent health, the help or support of the closest people is needed. The closest people can be from family, friends, even from nurses. In the theory of self care, support becomes one of the important things because when an individual gets a problem, he/she is unable to solve the problem independently without the support of the closest person.

Quality of life is a functional psychological capacity and social health as well as individual well-being. Quality of life is influenced by physical health, psychological conditions, the level of dependence on social relations, and the relationship of patients to the surrounding environment. He also explained that family support given to DM II patients can be viewed from four dimensions, namely: emotional dimensions, appreciation, instrumental, and participation (Skevington et al., 2004 in Nuraisyah et al., 2017). In this study, it was found that there was no correlation between family support and diabetes mellitus type 2 patients in Dander Health Center, which proved that there was no significant influence between physical health, psychological conditions, level of dependence on social relations, and patients relationships with the surrounding environment because in the results of this study there was no significant correlation between family support and patients quality of life.

The Correlation between Family Support and Quality of Life of Diabetes Mellitus Patient Type 2 on CDMP in Dander Health Center.

According to Orem, Dorothea et al (2001) in Ramawati, Dian., et al (2012) self care is an activity and initiative by an individual in fulfilling and maintaining life, health and well-being. Patients with diabetes mellitus will experience a psychological impact that will later result in despair to depression because of the long healing process and the effect of complications caused by it.

In a study conducted by Sari (2017), Oreme argues that knowledge is what makes individual can perform his/her own self-care. Self-awareness is the factor that determines the quality of life the most for people with DM. When nurses are able to optimalize DM patients' knowledge, their obedience, self care agency and self-care activities will also increase.

The factors that influence the behavior of self care according to the middle range theory of chronic illness are experience and skills, motivation, belief and cultural value, habits, functional, cognitive abilities, social support, facilities, and confidence including: self efficacy, self esteem. From the results of this study, it was found that between self care agency and quality of life of the DM type 2 patients in the Dander health care were not correlated. In addition, based on the results of the Spearman Rho test, it was shown that the results of the P-value in the sig column ( 2 tailed) obtained a value of 0.751 higher than the level of significant $\alpha 0.05(0,000<0.05)$ so that it can be concluded that $\mathrm{H} 0$ was accepted and $\mathrm{H} 1$ was rejected. The Spearman correlation value of 0.058 indicates that the direction of positive correlation had a very weak correlation.

From these results it can be concluded that quality of life of diabetes mellitus patient type 2 on CDMP in Dander Health Center has no correlation with the self care agency. This might be influenced by gender, employment, and family support of respondents in the Dander Health Center. Meanwhile, Riegel suggested that self care behavior itself is influenced by experience and skills, motivation, belief and cultural value, confidence, habits, 


\section{Journal Of Nursing Practice}

http://thejnp.org

ISSN: 2614-3488 (print); 2614-3496 (online)

Vol.3 No.1. October 2019. Page.22-32

functional and cognitive abilities, social support, and facilities (Barbara, 2012 in Ismatika \& Sholeha, 2017).

In contrast from the results of a research conducted by Chaidir, et al (2017) which concluded that there was a correlation between self care and the quality of life of patients with diabetes mellitus in Tigo Baleh Health Center which was directly proportional and had an average level of correlation, in which there were factors that influence the correlation of self care and the quality of life. It was known that the two results obtained were significant value (2-tailed) and the value of the correlation coefficient. Significant value (2-tailed) between self care quality of life for patients with diabetes mellitus in Tigo Baleh Health Center, which is $0.001(<0.05)$. It means that there was a significant correlation between self-care and quality of life of diabetes mellitus patients in Tigo Baleh Health Center. The difference in results from the research conducted by Chaidir, et al (2017) with the results of this study may be influenced by the characteristics of different respondents in the study.

\section{CONCLUSION}

From the results of the study it can be concluded that there is no correlation between self care agency with the quality life of diabetes mellitus patient type 2 on CDMP in Dander Health Center.. Based on the results of Spearman Rho test, it is shown that the results of the P-value in the sig column ( 2 tailed) obtained a value of 0.751 higher than the level of significant $\alpha 0.05(0,000<0.05)$ so it can be concluded that $\mathrm{H} 0$ was accepted and $\mathrm{H} 1$ was rejected. The Spearman correlation value of 0.058 indicates that the direction of positive correlation has a very weak correlation.

\section{REFERENCE}

Alligood,M.R., Tomey, A.M. 2010. Nursing theorists and their work. Mosby

Alligood, Martha Raile. 2006. Nursing theory: utilization and application. Elsevier-Mosby Brunner dan Sudarth.2013. KeperawatanMedikalBedah.Edisi 12.Jakarta.EGC.

Alvita, Galia Wardha. 2016. Hubungan Dukungan Keluarga Dengan Perawatan Diabetes Mellitus Pada Lansia Di Rumah, Kelurahan Cisalak Pasar Kota Depok. ISSN : 22528865 Vol. 2, No, 4-Maret, 2016.

Ansori\&Martiana. 2017. Hubungan Faktor Karakteristik Individu Dan Kondisi Pekerjaan Terhadap Stres Kerja Pada Perawat Gigi. The Indonesian Journal of Public Health, Vol. 12 No. 1, Juli 2017: 75-84.

Cahyoputro, Damar. Hubungan Antara Faktor Jenis Kelamin Dan Dukungan SosialDengan Tingkat Kecemasan Pada Lansia Di DesaLuwang, Gatak, Sukoharjo. Naskah Publikasi Fakultas Ilmu Kesehatan Universitas Muhammadiyah Surakarta.

Chaidir, dkk. 2017. Hubungan Self Care Dengan Kualitas Hidup Pasien Diabetes Melitus. Journal Endurance 2(2) June 2017 (132-144).

Chusmeywati, Vitta. 2016. Hubungan Dukungan Keluarga Terhadap Kualitas Hidup Penderita Diabetes Melitus Di RS PKU Muhammadiyah Yogyakarta Unit II. Naskah Publikasi Fakultas Kedokteran Dan Ilmu Kesehatan Universitas Muhammadiyah Yogyakarta.

Damayanti. (2015). Diabetes Mellitus \& Penatalaksanaan Keperawatan. Yogyakarta: Nuha Medika.

Demak \& Suherman. 2016. Hubungan Umur, Jenis Kelamin Mahasiswa Dan Pendapatan Orang Tua Dengan Tingkat Kecemasan Pada Mahasiswa Pendidikan Sarjana Program 


\section{Journal Of Nursing Practice}

http://thejnp.org

ISSN: 2614-3488 (print); 2614-3496 (online)

Vol.3 No.1. October 2019. Page.22-32

Studi Pendidikan Dokter FKIK Universitas Tadulako. Medika Tadulako, Jurnal Ilmiah Kedokteran, Vol. 3 No. 1.

Ismatika \& Sholeha. 2017. Hubungan Self Efficacy Dengan Perilaku Self Care Pasien Pasca Stroke Di Rumah Sakit Islam Surabaya. Jurnal Ilmiah Kesehatan, Vol. 10, No. 2 , Agustus 2017, Hal 139-148.

Kasron, dkk. 2016. Teori Keperawatan dan tokohnya. Jakarta : CV Trans Info Media

Khairani. 2014. Hubungan Dukungan Keluarga Dengan Kesepian Pada Lansia Di Desa Cucum Kecamatan Kuta Baro Aceh Besar. Idea Nursing Journal Vol.V No.1 2014.

Kurniawan, Indra. (2010) "Diabetes mellitus tipe 2 pada usia lanjut." Majalah Kedokteran Indonesia 60.12: 576-584 Nursalam. (2013). Metodologi Penelitian Ilmu Keperawatan Pendekatan Praktis. Jakarta: Salemba Medika.

Mirza, Rina. 2017. Memaksimalkan Dukungan Keluarga Guna Meningkatkan Kualitas Hidup Pasien Diabetes Mellitus. Jurnal JUMANTIK Volume 2 nomor 2, 2017.

Nuraisyah, dkk. 2017. Dukungan Keluarga dan Kualitas Hidup Pasien Diabetes Mellitus. Berita Kedokteran Masyarakat, Vol. 33 No. 01 Tahun 2017.

Perry, Potter.2005. Buku Ajar Fundamental Keperawatan. Edisi 4. Jakarta : EGC.

Perkeni. 2006. Konsensus Pengelolaan Diabetes pada Diabetes Melitus tipe 2. Perkeni: Jakarta.

Prasestiyo, H., \& Asnindari, L. N. (2017). Analisis Hubungan Faktor Lama Menderita Dan Komplikasi Penyakit Dengan Kualitas Hidup Pasien Diabetes Melitus Di Rumah Sakit PKU Muhammadiyah Bantul (Doctoral dissertation, Universitas' Aisyiyah Yogyakarta).

Sastroasmoro, S \& Ismail, S. (2014). Dasar-dasar Metodologi Penelitian Klinis. Edisi ke3. Sagung Seto. Jakarta

Sari, Ni Putu Wulan Purnama. 2017. Nursing Agency Untuk Meningkatkan Kepatuhan, SelfCare Agency (SCA) Dan Aktivitas Perawatan Diri Pada Penderita Diabetes Mellitus (DM). Jurnal Ners LENTERA, Vol. 5, No. 1, Maret 2017.

Siokal, Brajakson dkk. 2017. Falsafah dan Teori Dalam Keperawatan. Jakarta : CV Trans Info Media

Suhardingsih, AV. Sri., Mahfoed, Moh. Hasan.,Hargono, Rahmat., Nursalam. Peningkatan Self-Care Agency Pasien Dengan Stroke Iskemik Setelah penerapan Self-Care Regulation Model Jurnal Ners Vol. 7 No. 1 April 2012: 13-23.

Suprajitno. 2004. Asuhan Keperawatan Keluarga Aplikasi Dalam Praktik. Jakarta : EGC.

Utami, D.T., Karim, D., Agrina. 2014. Faktor-Faktor Yang Mempengaruhi Kualitas Hidup Pasien Diabetes Mellitus Dengan Ulkus Diabetikum. JOM PSIK Volume 1 Nomor 1 Oktober 2014.

Taluta, dkk. 2014. Hubungan Tingkat Kecemasan Dengan Mekanisme Koping Pada Penderita Diabetes Melitus Tipe II Di Poliklinik Penyakit Dalam Rumah Sakit Umum Daerah Tobelo Kabupaten Halmahera Utara. Ejournal keperawatan (e-Kp) Volume 2. Nomor 1. Februari 2014.

Yusra, Aini. 2011. Hubungan Antara Dukungan Keluarga Dengan Kualitas Hidup Pasien Diabetes Mellitus Tipe 2 Di Poliklinik Penyakit Dalam RSUP Fatmawati Jakarta. Naskah Publikasi Fakultas Keperawatan Universitas Indonesia : Depok. 